Original Research

\title{
Assessment of the Impacts of Terrestrial Determinants on Surface Water Quality at Multiple Spatial Scales
}

\author{
Ashfaq Khan', Afedullah Khan ${ }^{1,2 *}$, Fayaz Ahmad Khan', Liaqat Ali Shah², \\ Ateeq Ur Rauf ${ }^{2}$, Yasir Irfan Badrashi ${ }^{2}$, Wisal Khan ${ }^{2}$, Jehanzeb Khan ${ }^{3}$ \\ ${ }^{1}$ National Institute of Urban Infrastructure Planning, University of Engineering and Technology Peshawar, \\ 25000, Pakistan \\ ${ }^{2}$ Department of Civil Engineering, University of Engineering and Technology Peshawar (Bannu Campus), \\ 28100, Bannu, Pakistan \\ ${ }^{3}$ Higher Education Department KPK, Pakistan
}

Received: 26 March 2020

Accepted: 16 May 2020

\begin{abstract}
Investigating terrestrial determinants impacts on surface water quality is critical for watershed management. This research work reports the terrestrial determinants influence on surface water quality at multiple spatial scales at two trans-boundary rivers of Pakistan: The Ravi and Sutlej. This study is based on 18 physicochemical and trace elements $\left(\mathrm{pH}\right.$, turbidity, electrical conductivity (EC), $\mathrm{NO}_{3}$, total dissolved solid (TDS), chemical oxygen demand (COD), biological oxygen demand (BOD), dissolved oxygen (DO), hardness, total nitrogen, phosphorus, $\mathrm{Cu}, \mathrm{Pb}, \mathrm{As}, \mathrm{Cr}, \mathrm{Mn}, \mathrm{Zn}$, and $\mathrm{Cd}$ ) from 15 water quality monitoring stations. Terrestrial determinants especially village land use, coarse grained soil (high permeability) and mean slope (high erosion) can impair surface water quality. On the other hand, fine grained soil can protect stream health due to strong retention capacity and low infiltration capability. All spatial scales best explained terrestrial determinants-water quality relationship. Conservative practices are suggested at riparian as well as subbasin scale to account for the nearest and furthest pollutants sources. Restoration of riparian ecosystems should be a high priority for water quality enhancement in particular along the Ravi and Sutlej rivers and the two plains where there are intensive human activities at village level.
\end{abstract}

Keywords: terrestrial determinants, watershed management, land use, soil, surface water quality

*e-mail: afedullah@uetpeshawar.edu.pk 


\section{Introduction}

The influence of land alteration on natural ecosystems is widely assessed by investigating land use-stream water quality relationships. Intense agricultural activities, urban sprawl and increasing impervious surface area (ISA) have adverse impacts on stream health which includes increased surface runoff, nutrients and trace elements. Land use-water quality relationship implies that land development without proper land use policies decline surface water quality which badly impacts aquatic ecosystems.

The ecology and morphology of water bodies have been significantly changed owing to anthropogenic activities at local and regional scale around the globe. Land use land cover (LULC), soil texture, socioeconomic activities and topographic features have prominent impacts on water quality at watershed scale [1]. LULC, topographical condition, soil texture and other climatic conditions are mainly responsible for the transport of pollutants at catchment scale $[2,3]$. Hence, watershed managers are constantly seeking the relationship between various water quality parameters and the aforementioned determinants which is a challenging task [4]. It is also necessary to adopt multiple spatial scale analysis to determine the sink/source relationship. Multiple spatial scale analysis is important as it links LULC with biological, physicochemical and trace elements at different scales. LULC in the upstream of a river or station plays vital role in the contamination of water bodies [5]. [6] developed LULC-water quality relationship at riparian scale. Riparian buffer varies from $8 \mathrm{~m}$ to $200 \mathrm{~m}$. Scale of the study area give an idea about the strength of LULCwater quality relationship which is adopted for policy formulation [7]. It is well-founded knowledge that hydrological models are extensively used for water quality modeling. However, hydrological models need many variables as well as long historical record for model calibration and validation. Due to these limitations, statistical techniques are preferred over hydrological models [7].

Irrigation tail water discharge enhance nutrients concentration in surface waters which includes nitrogen, phosphorous etc. [8]. Intense ploughing loose soil particles which fuel the transport of nutrients from agricultural lands. The eroded nutrients cause eutrophication which deplete dissolved oxygen [9]. Besides, over-fertilization plays vital role in surface water contamination [4]. Source to sink transport of nutrients i.e. nitrogen and phosphorous depends on many factors which includes type of nutrient, climatic factors, distance through which the water flows, streamlines, surface runoff, leaching and erosion [10].

Urban settlement has strong correlation with trace elements and COD [11]. Surface water quality is badly effected by intense anthropogenic activities at urban communal level [12]. Surficial geology and steep slope speed up surface water contamination [4, 13]. Intense human activities produce different non-point source (NPS) pollutants, trace elements, sediments, pathogens and other contaminants [14-16]. Excessive ISA affects urban hydrology by reducing infiltration and time of concentration, and enhancing discharge which speed up soil erosion [7, 17]. Water bodies in close proximity of urban area are highly polluted owing to the aforementioned reasons [18].

Literature shows that forest land use plays friendly role in protecting and maintaining stream health. Forest land use declines the concentration of trace elements and COD [19]. Forests reduce soil erosion by reducing overland flow and enhance infiltration [20]. Deforestation increases air temperature which ultimately increase water temperature. Deforestation enhances soil erosion and decline dissolved oxygen concentration in surface waters. Deforestation decreases nutrient recycling and sediments transport, and increase leaching phenomenon [7, 11, 13, 21]. Deforestation enhances the concentration of nitrate $\left(\mathrm{NO}_{3}\right)$ in the nearby soil and waterbodies owing to lower uptake of nutrients and high decay rate of plants and vegetation. Nitrate concentration is $50 \%$ higher in forested watersheds [22]. Useful biological nutrients are retained by plants and vegetation which helps in protecting nearby waterbodies $[3,4]$.

The principal aim of this research article is to investigate terrestrial determinants-water quality relationship at two trans-boundary rivers of Pakistan: The Ravi and Sutlaj. The major contribution of this research article is to develop the relationship between water quality and terrestrial determinants (top and sub soil texture (sand, silt, clay and gravel) and anthropogenic biomes (dense settlements, villages, croplands, rangelands, forested and wildlands)), topographic and social factors at multiple spatial scales.

\section{Material and Methods}

\section{Study Area Description}

The study area includes 6 sampling points located along the Ravi (Ravi 1, Ravi 2 and Ravi 3) and Sutlej (Sutlej 1, Sutlej 2 and Sutlej 3) rivers, seven drains (Shahdara Drain, Babu Sabu Drain, Hadiara Drain-1, Hadiara Drain-2, Madvana Drain, Sukhrawa Drain, Upper Chenab Canal) entering into Ravi river and two drains entering into Sutlej river (Rangewala/Pandoki Drain, Chishtian Drain) as shown in Fig. 1.

\section{Data Collection}

\section{Water Quality Data}

Water quality data was collected from Pakistan Council of Research in Water Resources (PCRWR). This study is based on 18 physicochemical and trace elements ( $\mathrm{pH}$, turbidity, EC, NO3, TDS, COD, BOD, 


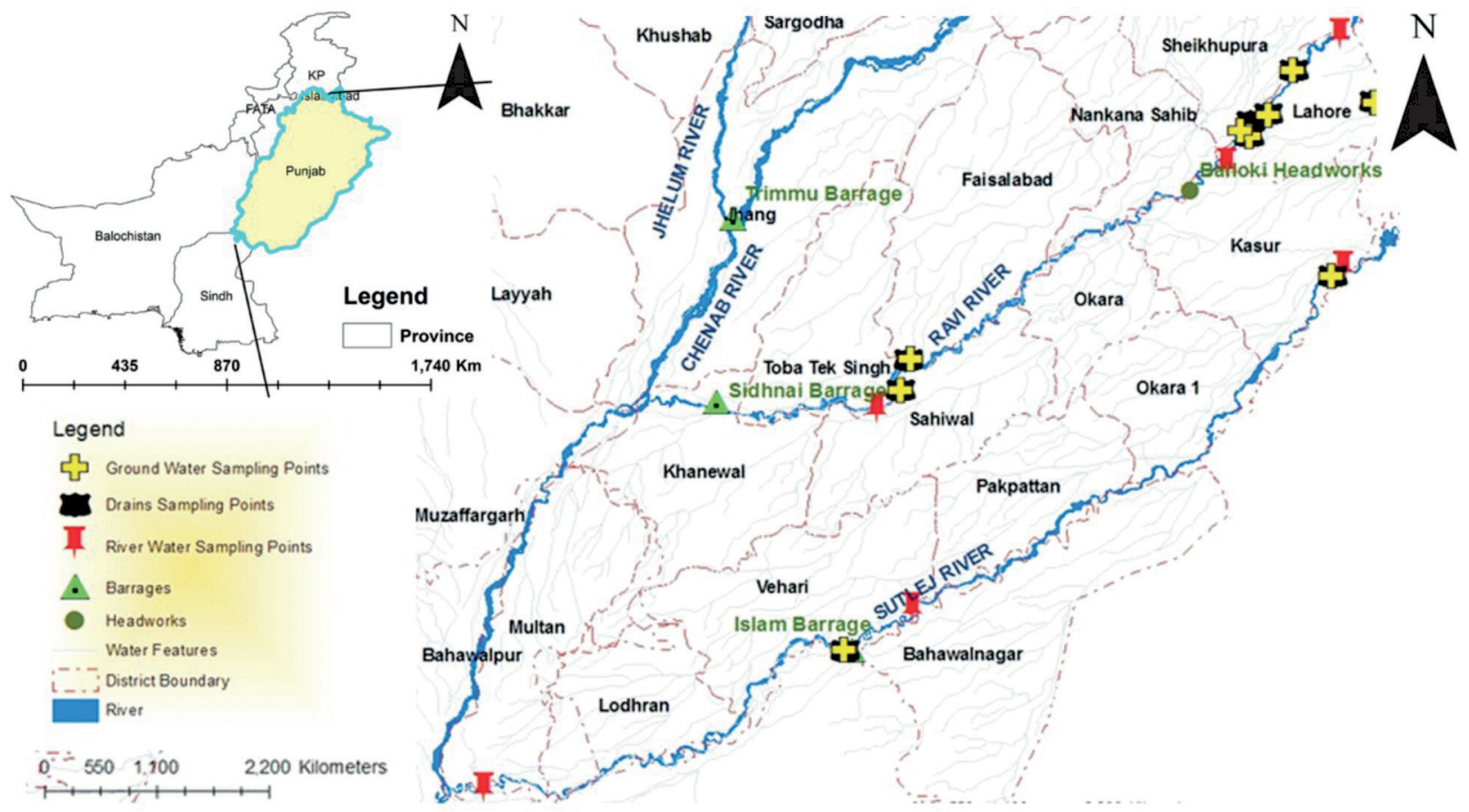

Fig. 1. Study area map showing water sampling points.

$\mathrm{DO}$, hardness, total nitrogen, phosphorus, $\mathrm{Cu}, \mathrm{Pb}, \mathrm{As}$, $\mathrm{Cr}, \mathrm{Mn}, \mathrm{Zn}$, and $\mathrm{Cd}$ ) from 15 water quality monitoring stations: 6 monitoring sites located along the Ravi and Sutlej rivers and 9 monitoring stations located along the drains entering Ravi and Sutlej rivers. Water quality samples were regularly collected and tested in the PCRWR laboratory on a monthly basis from August 2015 to July 2016. The water samples were collected and analyzed using American Public Health Association (APHA) standard methods (APHA, 2012).

\section{Terrestrial Determinants and Digital Elevation Model (DEM) Data}

DEM data was downloaded from Shuttle Radar Topography Mission (SRTM) which was used for subbasins delineation. Anthropogenic biomes data was downloaded from Socioeconomic Data and Applications Center (SEDAC) which consists of six major classes which include dense settlements, villages, croplands, rangelands, forested and wildlands. Soil data was downloaded from World Harmonized Soil Database (HWSD).

\section{Statistical Analysis}

Pearson correlation and linear regression analysis were used to assess the relationship between terrestrial determinants (anthropogenic biomes and surficial geology) and water quality parameters [23]. Before statistical analysis, all variables were tested for normal distribution using Shapiro-Wilk test with significance level of $p<0.05$. Skewed variables data were normalized using log transformation. Generally, mean and median concentrations of water quality parameters are adopted to develop linear relationship. Median values exclude the effects of extreme conditions (outliers) and gives an idea about the general conditions. Here, the outliers effects were lessened by adopting median values. Moreover the data was again screened for outliers presence using interquartile range (IQR) approach. Any number $>(1.5 \mathrm{x} \mathrm{IQR}+$ third quartile) or $<$ (first quartile - $1.5 \times \mathrm{IQR})$ is suspected outlier.

\section{Sub Watershed Delineation}

Spatial analyst tools (Hydrology) is used for the delineation of sub basin for each water quality monitoring station using geographic information system (GIS) [4, 7]. Within each subbasin, parallel buffers of $500 \mathrm{~m}, 1000 \mathrm{~m}$ and $1500 \mathrm{~m}$ were delineated using proximity analysis tool (buffer). Terrestrial determinants and physiographic characteristics were extracted for each monitoring station at multiple spatial scales. Later, the extracted determinants were linked with water quality parameters using the aforementioned statistical approaches.

\section{Results and Discussion}

\section{Biome and Soil Texture Data Extraction Using GIS}

Delineated sub-basins are demonstrated by Fig. 2 . Anthropogenic biomes and soil texture data is extracted 


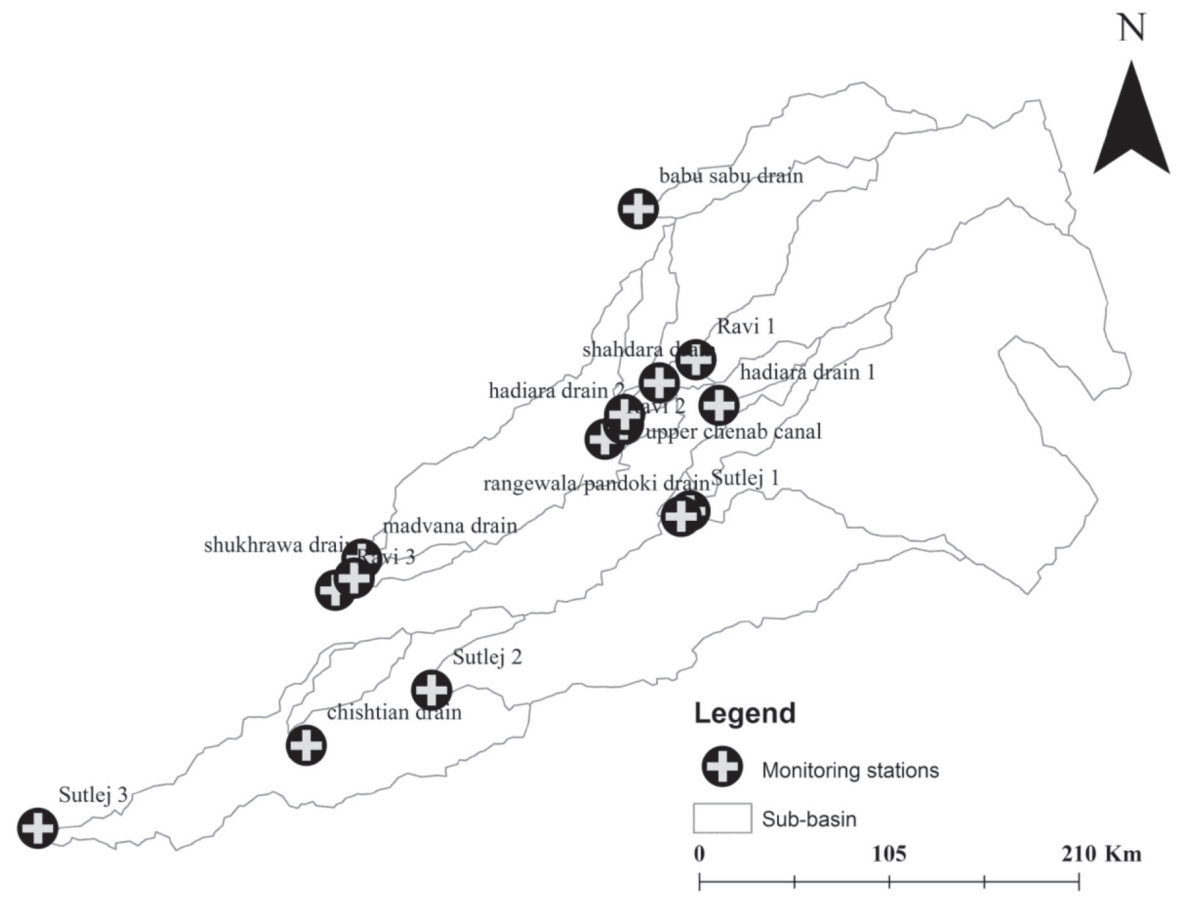

Fig. 2. Delineated sub-basins for the selected water quality monitoring stations.

Chishtian drain

Rangewala/pandoki drain

Upper chenab canal

Shukhrawa drain

Madvana drain

Hadiara drain 2

Hadiara drain 1

Babu sabu drain

Shahdara drain

Sutlej 3

Sutlej 2

Sutlej 1

Ravi 3

Ravi 2

Ravi 1 Rangewala/pandoki drain

Upper chenab canal Shukhrawa drain

Madvana drain

Hadiara drain 2

Hadiara drain 1

Babu sabu drain

Shahdara drain

Sutlej 3

Sutlej 2

Sutlej 1

Ravi 3

Ravi 2

Ravi 1

\section{$\square$ Rangelands $\square$ Dense settlement $\square$ Croplands $\square$ Villages}

(a) $500 \mathrm{~m}$ buffer

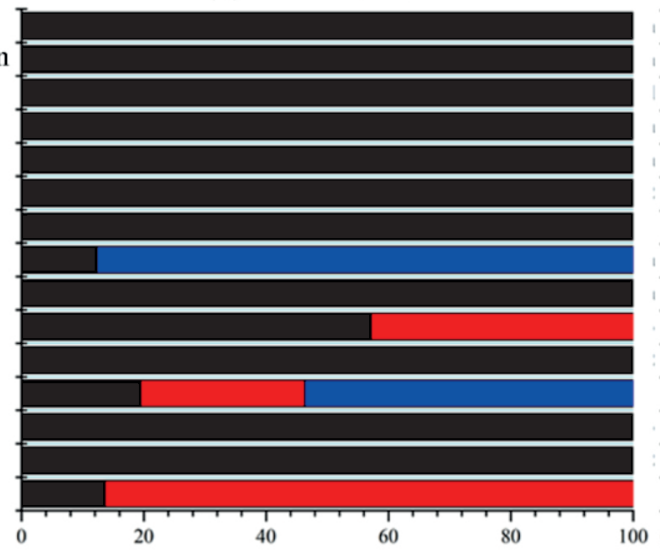

(b) $1000 \mathrm{~m}$ buffer

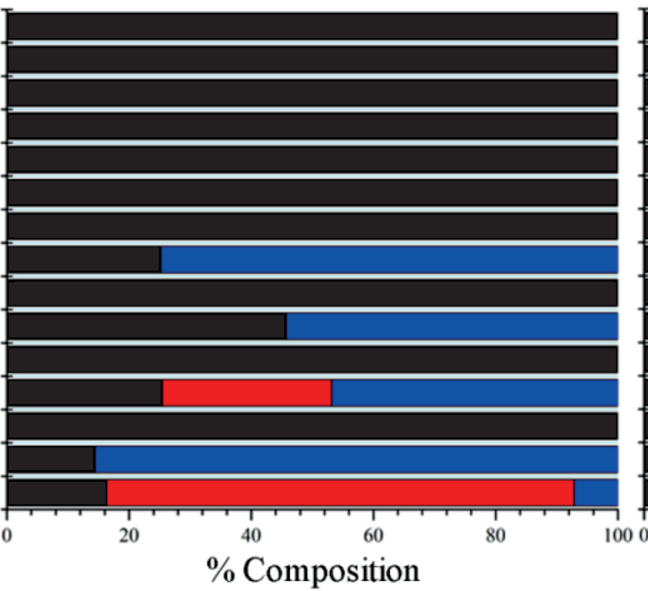

(c) $1500 \mathrm{~m}$ buffer

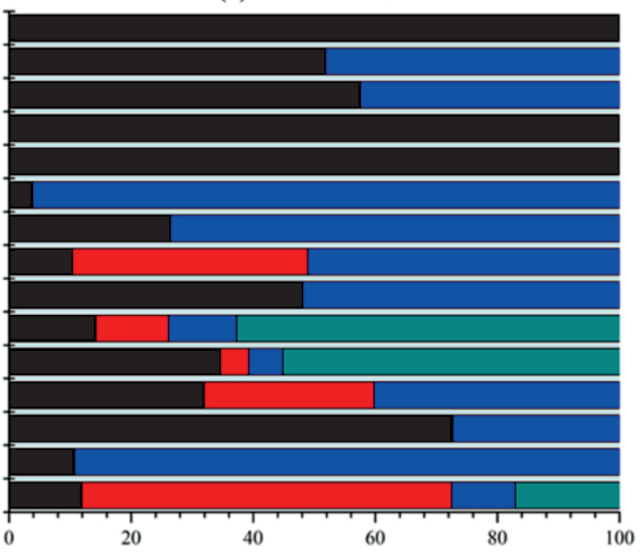

(d) Subbasin

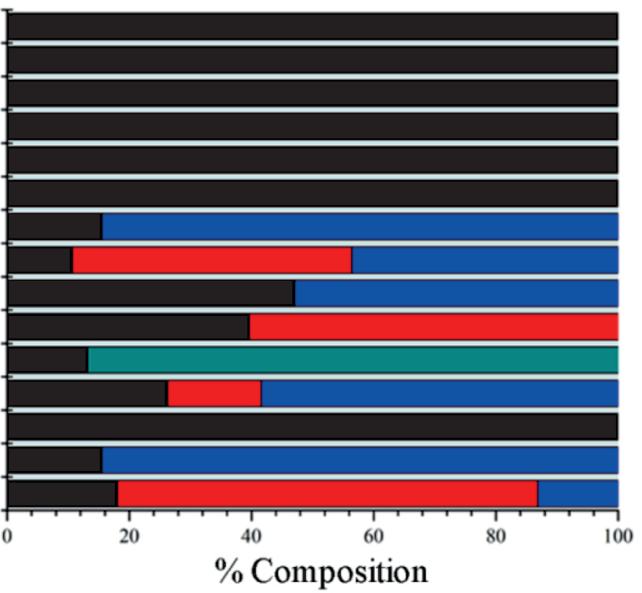

Fig. 3. Anthropogenic biomes percentage composition at multiple spatial scales. 


\begin{tabular}{|l|l|l|}
\hline Sub clay $\square$ Sub silt $\square$ Sub sand $\square$ Sub gravel \\
$\square$ Top clay $\square$ Top silt $\square$ Top sand $\square$ Top gravel \\
\hline
\end{tabular}

(a) $500 \mathrm{~m}$ buffer

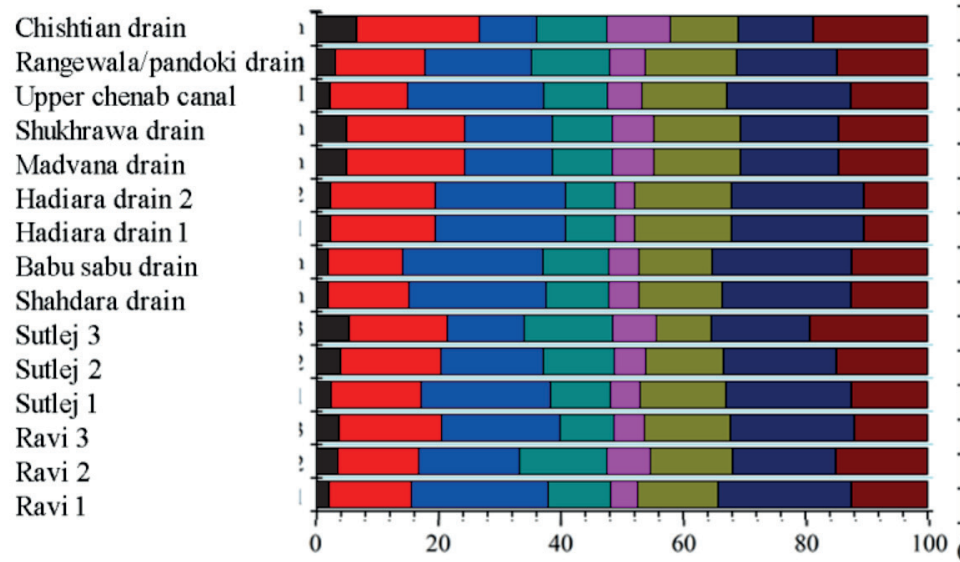

(c) $1000 \mathrm{~m}$ buffer

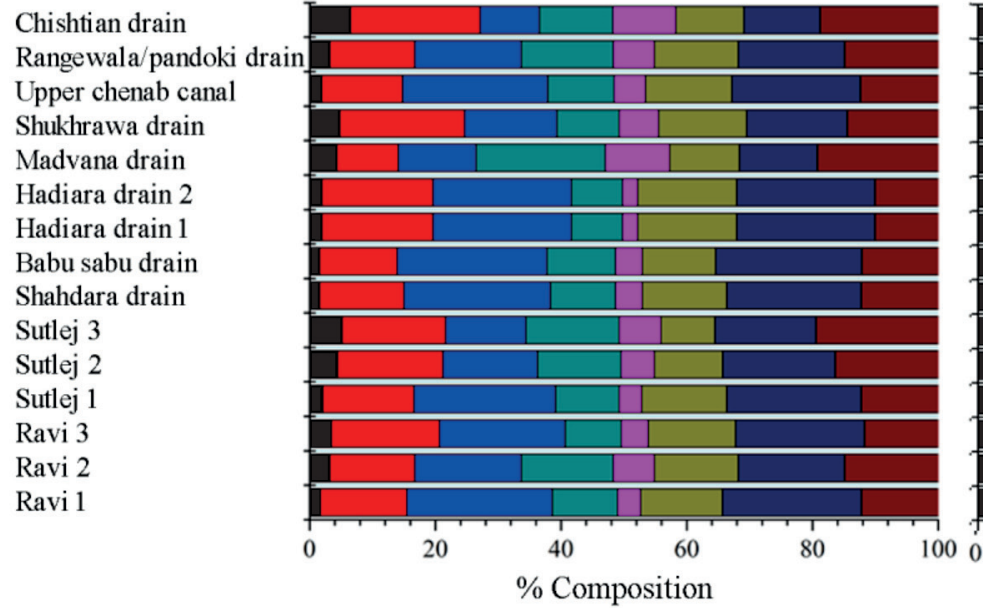

Chishtian drain Upper chenab canal Shukhrawa drain

Madvana drain

Hadiara drain 2

Hadiara drain 1

Babu sabu drain

Shahdara drain

Sutlej 3

Sutlej 2

Sutlej 1

Ravi 3

Ravi 2

Ravi 1

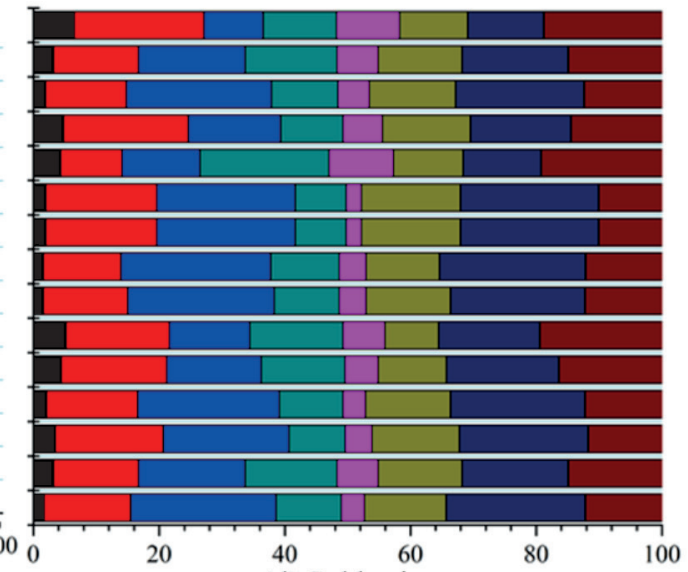

(d) Subbasin

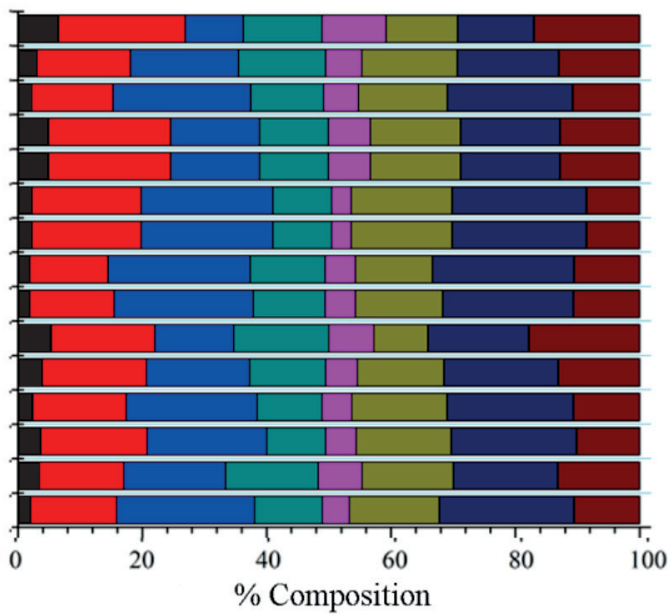

Fig. 4. Top and sub soil texture percentage composition at multiple spatial scales.

for the delineated subbasin and parallel buffers using GIS. The extracted anthropogenic biomes percentage composition data is demonstrated by Fig. 3. Village biome is dominant at all spatial scales. Fig. 4 shows top and sub soil texture percentage composition at all spatial scales. Both top and sub soil texture shown approximately equal percentage composition at all spatial scales.

\section{Relationship of Terrestrial Determinants with Water Quality Parameters}

Before statistical analysis, $\mathrm{EC}, \mathrm{NO}_{3}, \mathrm{As}, \mathrm{Zn}, \mathrm{Cr}, \mathrm{Cd}$ and $\mathrm{Ni}$ were found skewed and were $\log$ transformed. Skewed terrestrial, social and topographic variables data were normalized at $500 \mathrm{~m}$ (mean population, standard deviation of slope and villages), 1000m (mean population, mean slope, standard deviation of slope and villages) and $1500 \mathrm{~m}$ (mean population, mean slope, standard deviation of slope and villages) scales as demonstrated by Table 1 .
Pearson correlation was carried out to figure out the relationships between terrestrial determinants and water quality parameters at multiple spatial scales as obvious from Fig. 5.

Relationship of Water Quality Parameters with Terrestrial Determinants at Multiscale Riparian Buffers

\section{0 m Riparian Buffer Scale}

Mean population is positively related to COD and BOD [23, 24]. Literature shows that high anthropogenic activities enhance surface water pollution $[13,21]$. Mean population is negatively linked with DO because high anthropogenic activities increases surface water pollution which enhance DO consumption $[23,24]$. The positive relationship between village biome and hardness, $\mathrm{COD}, \mathrm{BOD}, \mathrm{N}, \mathrm{Cu}, \mathrm{Mn}$ and $\mathrm{Pb}$ shows that high human activities deteriorates surface water quality [12]. The positive linkage between mean 
Table 1. Results of Shapiro-Wilk test for normality assessment of surface water quality, social, topographical and terrestrial determinants at multiple spatial scales.

\begin{tabular}{|c|c|c|c|c|c|c|c|c|c|}
\hline \multicolumn{2}{|c|}{ All scale } & \multicolumn{2}{|c|}{$500 \mathrm{~m}$ buffer scale } & \multicolumn{2}{|c|}{$1000 \mathrm{~m}$ buffer scale } & \multicolumn{2}{|c|}{$1500 \mathrm{~m}$ buffer scale } & \multicolumn{2}{|c|}{ Subbasin scale } \\
\hline $\begin{array}{c}\text { Water } \\
\text { quality } \\
\text { parameter }\end{array}$ & $\begin{array}{l}\text { Shapiro- } \\
\text { Wilk }\end{array}$ & $\begin{array}{c}\text { Terrestrial } \\
\text { determinants }\end{array}$ & $\begin{array}{l}\text { Shapiro- } \\
\text { Wilk }\end{array}$ & $\begin{array}{c}\text { Terrestrial } \\
\text { determinants }\end{array}$ & $\begin{array}{l}\text { Shapiro- } \\
\text { Wilk }\end{array}$ & $\begin{array}{c}\text { Terrestrial } \\
\text { determinants }\end{array}$ & $\begin{array}{l}\text { Shapiro- } \\
\text { Wilk }\end{array}$ & $\begin{array}{c}\text { Terrestrial } \\
\text { determinants }\end{array}$ & $\begin{array}{l}\text { Shapiro- } \\
\text { Wilk }\end{array}$ \\
\hline $\mathrm{Ph}$ & 0.67 & $\begin{array}{l}\text { Mean popula- } \\
\text { tion* }\end{array}$ & .775 & $\begin{array}{c}\text { Mean popula- } \\
\text { tion* }\end{array}$ & 0.10 & $\begin{array}{l}\text { Mean popula- } \\
\text { tion* }\end{array}$ & .117 & $\begin{array}{c}\text { Mean popu- } \\
\text { lation }\end{array}$ & 0.35 \\
\hline $\mathrm{EC}^{*}$ & 0.78 & Mean slope & .307 & Mean slope & 0.59 & Mean slope* & .080 & Mean slope & 0.12 \\
\hline TDS & 0.02 & $\begin{array}{l}\text { Std dev } \\
\text { slope* }\end{array}$ & .016 & Std dev slope & 0.68 & Std dev slope* & .173 & Std dev slope & 0.54 \\
\hline NO3* & 0.21 & Villages* & .042 & Villages* & 0.50 & Villages* & .333 & Villages & 0.73 \\
\hline Turbidity & 0.05 & Top gravel & 0.89 & Top gravel & 0.90 & Top gravel & 0.99 & $\begin{array}{c}\text { Dense settle- } \\
\text { ment }\end{array}$ & 0.36 \\
\hline Hardness & 0.42 & Top sand & 0.11 & Top sand & 0.12 & Top sand & 0.21 & Top gravel & 1.00 \\
\hline COD & 0.18 & Top silt & 0.83 & Top silt & 0.84 & Top silt & 0.63 & Top sand & 0.91 \\
\hline BOD & 0.14 & Top clay & 0.62 & Top clay & 0.64 & Top clay & 0.92 & Top silt & 0.70 \\
\hline DO & 0.01 & Sub gravel & 0.53 & Sub gravel & 0.55 & Sub gravel & 0.83 & Top clay & 0.78 \\
\hline Nitrogen & 0.34 & Sub sand & 0.06 & Sub sand & 0.08 & Sub sand & 0.09 & Sub gravel & 0.88 \\
\hline PO4 & 0.02 & Sub silt & 0.76 & Sub silt & 0.79 & Sub silt & 0.96 & Sub sand & 0.22 \\
\hline As* & 0.13 & Sub clay & 0.69 & Sub clay & 0.70 & Sub clay & 0.99 & Sub silt & 0.89 \\
\hline $\mathrm{Cu}$ & 0.02 & & & & & & & Sub clay & 0.60 \\
\hline $\mathrm{Zn}^{*}$ & 0.94 & & & & & & & & \\
\hline $\mathrm{Mn}$ & 0.60 & & & & & & & & \\
\hline $\mathrm{Cr}^{*}$ & 0.23 & & & & & & & & \\
\hline $\mathrm{Cd}^{*}$ & 0.12 & & & & & & & & \\
\hline $\mathrm{Pb}$ & 0.12 & & & & & & & & \\
\hline $\mathrm{Ni}^{*}$ & 0.14 & & & & & & & & \\
\hline B & 0.17 & & & & & & & & \\
\hline TSS & 0.22 & & & & & & & & \\
\hline
\end{tabular}

* Log 10 transformed variable at multiple spatial scales

slope and Boron (B) highlight that step slope fuels Boron containing soil erosion which impairs surface water quality [8]. EC, TDS, Water Hardness, Cr, Cd and $\mathrm{B}$ have positive relationship with the top gravel. Similarly sand has also positive correlation with $\mathrm{Mn}$, $\mathrm{Cr}$, and $\mathrm{Cd}$. High permeability of coarser materials (gravels and sand) favor pollutants flow which impairs surface water quality. On the other hand, fine particles (silt and clay) are negatively associated with water quality parameters (EC, TDS, $\mathrm{NO}_{3}, \mathrm{As}, \mathrm{Cr}$ and $\mathrm{Cd}$ ) which may be due to low permeability of fine materials. High permeability of sub gravels favors EC, TDS, As, Cr, $\mathrm{Cd}$ and hardness contamination. Similarly sub silt and sub clay prevents the entry of EC, TDS, Hardness, $\mathrm{As}, \mathrm{Cr}$ and $\mathrm{Cd}$ to surface waters due to its low permeability [4].

\section{0 m Riparian Buffer Scale}

Mean population is positively linked with COD and BOD, and negatively correlated with DO [23, 24]. High anthropogenic activities cause surface water pollution and thereby decreases DO. Mean slope has positive relationship with Turbidity and $\mathrm{PO}_{4}$ which may be due enhanced soil erosion fueled by step slope $[23,25,26]$. Village biome is positively correlated with hardness, $\mathrm{COD}, \mathrm{BOD}, \mathrm{N}, \mathrm{Cu}, \mathrm{Mn}$ and $\mathrm{Pb}$ while negatively linked with $\mathrm{DO}$ which shows that high anthropogenic activities deteriorates surface water quality. $\mathrm{EC}, \mathrm{Cr}, \mathrm{Cd}$ and $\mathrm{B}$ has positive relationship with top gravels and sand as more will be the permeability more will be the flow of water and pollutants through it. Top silt and top clay were negatively correlated with (EC, $\mathrm{Cr}$ and $\mathrm{Cd}$ ) and (TDS, $\mathrm{NO}_{3}$ and As) respectively. Sub gravel and sub sand has 
(a) $500 \mathrm{~m}$ buffer
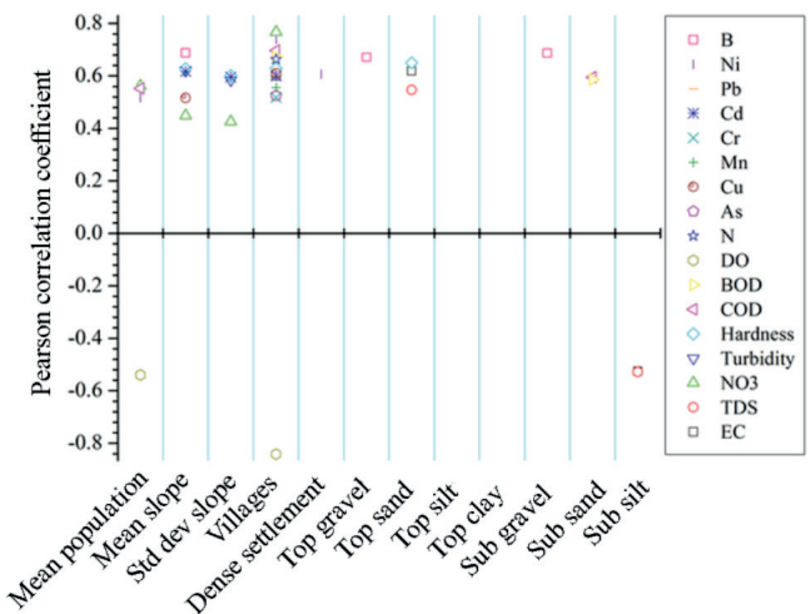

(b) $1000 \mathrm{~m}$ buffer
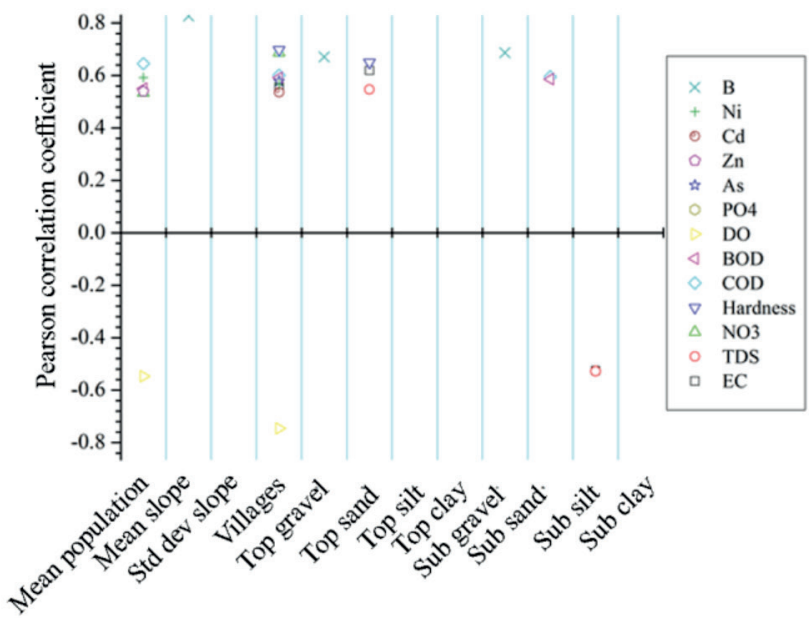

(c) $1500 \mathrm{~m}$ buffer
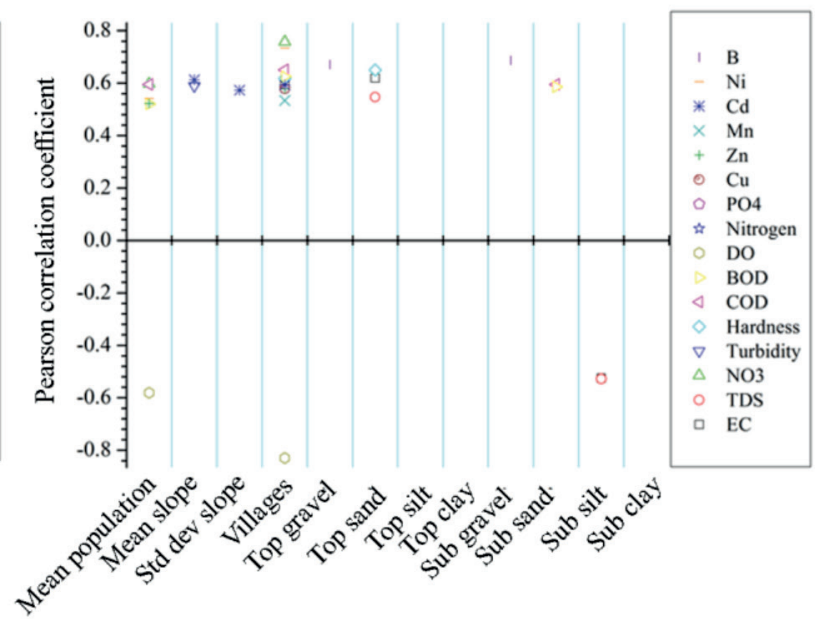

(d) Subbasin
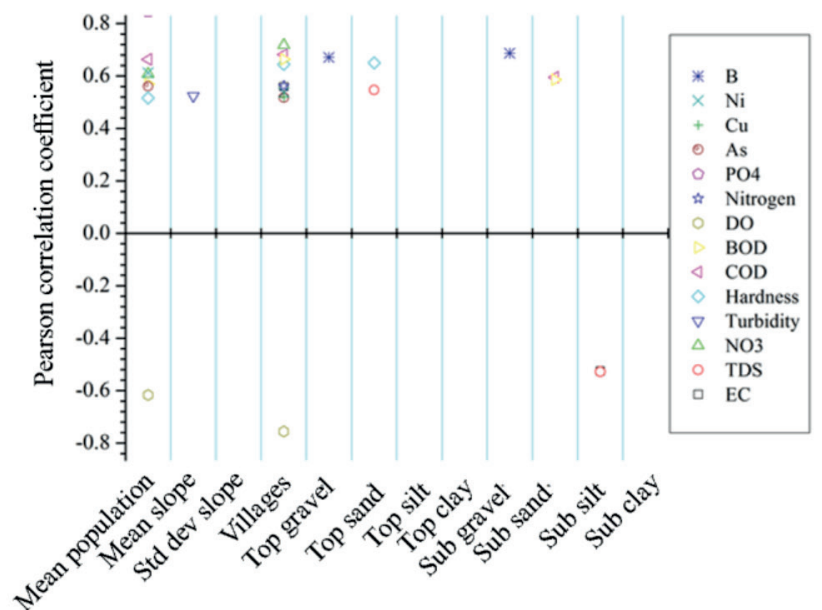

Fig. 5. Pearson correlation between terrestrial determinants and water quality parameters at multiple spatial scales.

positive correlation with (EC, TDS, As, Cr, Cd) and (COD, BOD and $\mathrm{Mn}$ ) respectively. Negative significant statistical relation exists between finer particles (sub silt and sub clay) and EC, TDS, Hardness, As, $\mathrm{Cr}$ and $\mathrm{Cd}$. This shows that permeability of soil plays vital role in polluting surface waters [4].

\section{0 m Riparian Buffer Scale}

Mean population is positively linked with Hardness, COD BOD and $\mathrm{Mn}$ while negatively correlated with DO which shows that intense population fuels surface water pollution [23, 24]. Turbidity is directly related to the mean slope which may be due to soil erosion. Village biome is positively linearly related with hardness, $\mathrm{COD}, \mathrm{BOD}, \mathrm{N}, \mathrm{Cu}, \mathrm{Mn}$ and $\mathrm{Pb}$ while it is negatively correlated with $\mathrm{DO}$ which may due to intense human activities [27]. EC, Cr, Cd and B have positive relationship with the top gravel and top sand. A negative correlation was found between silt, EC, $\mathrm{Cr}$ and $\mathrm{Cd}$. Top clay is negatively linked with TDS, $\mathrm{NO}_{3}$ and As. Sub gravel is positively tied with EC and TDS.
Sub sand is positively correlated with COD, BOD and Mn. Sub silt is negatively linked with EC, TDS, and As. This show that both top and sub geology regulate surface water pollution via permeability. Soil with higher permeability enhance surface water pollution and vice versa [4].

\section{Relationship of Water Quality Parameters with Terrestrial Determinants at Sub-Basin Scale}

Mean population is positively and negatively linked with COD and DO respectively [24]. Mean slope has a positive correlation with Turbidity, $\mathrm{Cu}, \mathrm{B}$ and $\mathrm{PO}_{4}$ which may be due to intense human activities [23, 26]. Village biome is positively and negatively linked with (hardness, COD, BOD, N, Cu, Mn and Pb) and DO respectively which may be due to intense anthropogenic activities. Top gravel and sand are positively correlated with EC, TDS, Hardness, Cr, Cd and B. Top silt is negatively correlated with $\mathrm{EC}, \mathrm{Cr}$ and $\mathrm{Cd}$. Sub gravel and sub sand are positively associated with (EC, Cr, Cd 
Table 2. Linear models between water quality and terrestrial determinants at $500 \mathrm{~m}$ buffer scale.

\begin{tabular}{|c|c|c|}
\hline WQ Variables & Linear Regression Equation & $\mathrm{R}^{2}$ \\
\hline $\mathrm{EC}^{*}$ & $2.803-0.316$ Top gravel +0.025 Top sand -0.01 Sub silt & 0.53 \\
\hline TDS & $1234+45.53$ Top sand -44.22 Sub silt & 0.34 \\
\hline $\mathrm{NO}_{3}^{*}$ & 3.371 - 0.7 Mean population* - 0.8 Villages* & 0.51 \\
\hline Hardness & 87.66 - 107.76 Villages* +7.12 Top Sand & 0.68 \\
\hline COD & 1117 - 164 Villages* - 305 Mean population* + 7 Sub sand & 0.64 \\
\hline BOD & $636-178$ Mean population* -124 Villages* +6 Sub sand & 0.55 \\
\hline DO & $-4.7+1.8$ Mean population* +2.4 Villages $*$ & 0.67 \\
\hline $\mathrm{As}^{*}$ & $1.2-0.3$ Villages* & 0.33 \\
\hline $\mathrm{B}$ & $31-0.35$ Mean slope +0.068 Top gravel +0.054 Sub gravel & 0.76 \\
\hline
\end{tabular}

* Log 10 transformed variable at $500 \mathrm{~m}$ buffer scale

Table 3. Linear models between water quality and terrestrial determinants at $1000 \mathrm{~m}$ buffer scale.

\begin{tabular}{|c|c|c|}
\hline WQ Variables & Linear Regression Equation & $\mathrm{R}^{2}$ \\
\hline $\mathrm{EC}^{*}$ & $2.66-0.012$ Villages* +0.028 Top sand -0.009 Sub Silt & 0.63 \\
\hline $\mathrm{NO}_{3}^{*}$ & $1.89-0.000224$ Mean population* - 0.026 Villages* & 0.67 \\
\hline Hardness & 24 - 2.9 Villages $*+8.3$ Top sand & 0.68 \\
\hline COD & $25.94-0.05$ Mean population* - 6.1 Villages* + 18.22 Sub Sand & 0.61 \\
\hline BOD & 171.7 - 0.02 Mean population* - 4.85 Villages* +17.54 S Sand & 0.55 \\
\hline DO & $0.27+0.0005$ Mean population* +0.08 Villages* & 0.75 \\
\hline $\mathrm{N}$ & 38 - 0.66 Villages* & 0.33 \\
\hline $\mathrm{Zn} *$ & $-0.15-0.01$ Villages $*+0.0001$ Mean population* & 0.40 \\
\hline $\mathrm{Ni}^{*}$ & $1.66+0.0001$ Mean population* - 0.012 Villages* & 0.58 \\
\hline $\mathrm{Cu}$ & 1.29 - 0.02 Villages* & 0.34 \\
\hline $\mathrm{Cd}^{*}$ & $8.1-0.083$ Mean slope +0.012 Std dev slope - 0.018 Villages* & 0.51 \\
\hline
\end{tabular}

* Log 10 transformed variable at $1000 \mathrm{~m}$ buffer scale

"Std dev" is the abbreviation of "standard deviation"

Table 4. Linear models between water quality and terrestrial determinants at $1500 \mathrm{~m}$ buffer scale.

\begin{tabular}{|c|c|c|}
\hline WQ Variables & Linear Regression Equation & $\mathrm{R}^{2}$ \\
\hline $\mathrm{EC}^{*}$ & $3.254-0.26$ Villages* +0.02 Top sand -0.01 Sub silt & 0.52 \\
\hline $\mathrm{NO}_{3}^{*}$ & $4.09-0.748$ Mean population* - 0.66 Villages* & 0.59 \\
\hline $\mathrm{COD}$ & $1150-308$ Mean population* - 196 Villages* + 7.3 Sub silt & 0.52 \\
\hline $\mathrm{BOD}$ & $719-166$ Mean population* - 156 Villages* + 4.18 Sub silt & 0.71 \\
\hline $\mathrm{PO} 4$ & $6.6-1.8$ Mean population* & 0.38 \\
\hline $\mathrm{As} *$ & $2.15-0.33$ Mean population* - 0.13 Villages* & 0.27 \\
\hline $\mathrm{Cu}$ & $1.5-0.57$ Villages* & 0.44 \\
\hline $\mathrm{Ni} *$ & $3.66-0.74$ Mean population* - 0.24 Villages* & 0.48 \\
\hline $\mathrm{B}$ & $0.71+0.11$ Top gravel + 0.14 Sub gravel & \\
\hline
\end{tabular}

* Log 10 transformed variable at $1500 \mathrm{~m}$ buffer scale

"Std dev" is the abbreviation of "standard deviation" 
Table 5. Linear models between water quality and terrestrial determinants at sub-basin scale.

\begin{tabular}{|c|c|c|}
\hline WQ Variables & Linear Regression Equation & $\mathrm{R}^{2}$ \\
\hline $\mathrm{EC}^{*}$ & $2.6-0.003$ Villages +0.028 Top sand - 0.008 Sub silt & 0.64 \\
\hline $\mathrm{NO}_{3}^{*}$ & $1.68-0.0002$ Mean population - 0.048 Villages & 0.68 \\
\hline $\mathrm{COD}$ & $27.55-0.05$ Mean population - 1.95 Villages + 16.71 Sub Sand & 0.60 \\
\hline $\mathrm{BOD}$ & $285.14-1.42$ Villages +20.86 Sub Sand & 0.83 \\
\hline $\mathrm{DO}$ & $0.17+0.001$ Mean population +0.02 Villages & 0.44 \\
\hline $\mathrm{N}$ & $38.00-0.19$ Villages & 0.44 \\
\hline $\mathrm{Cu}$ & $10.57-0.11$ Mean slope - 0.005 Villages & 0.31 \\
\hline $\mathrm{Mn}$ & $0.49-0.002$ Villages & 0.28 \\
\hline $\mathrm{As} *$ & $1.23-0.002$ Villages & 0.27 \\
\hline $\mathrm{Cr} *$ & $1.78-0.006$ Villages & 0.51 \\
\hline $\mathrm{Cd} *$ & $17.03-0.004$ Villages -0.182 Mean slope -0.006 Std dev slope & 0.36 \\
\hline $\mathrm{Pb}$ & $18.19-0.07$ Villages & 0.74 \\
\hline $\mathrm{Ni} *$ & $1.84-0.005$ Villages - 0.006 Dense settlement +0.0002 Mean population & 0.75 \\
\hline $\mathrm{B}$ & $57-0.655$ Mean slope - 0.226 Top gravel +0.302 Sub gravel & \\
\hline
\end{tabular}

* Log 10 transformed variable at subbasin scale

"Std dev" is the abbreviation of "standard deviation"

and $\mathrm{B}$ ) and (COD and BOD). Sub silt and sub clay are negatively correlated with EC, TDS, $\mathrm{Cr}$ and $\mathrm{Cd}$. It shows that mean population, mean slope, coarse materials and village biome deteriorate surface water quality while fine material protects stream health.

Physical Insights into the Correlation Results

The results of the current study implied that positive correlation exists between water quality parameters (except DO), and mean population, village land use, coarse grained soil (gravel and sand) and topographic characteristics at all spatial scales. On the other hand, negative correlation was found between water quality parameters and fine grained materials (silt and clay) at all spatial scales. Terrestrial determinants especially village land use, coarse grained soil (high permeability) and physiographic characteristic of watershed, mean slope (high erosion) can impair surface waters. On the other hand, fine grained soil can protect stream health due to strong retention capacity and low infiltration capability.

\section{Linear Models of Terrestrial Determinants with Water Quality Parameters}

To quantitatively investigate the associations between terrestrial determinants and water quality, multiple linear regression was applied at multiple spatial scales. Villages and coarse grained soil were the strong predictors of water quality as intense human activities at village level and high hydraulic conductivity of coarse grained soil can deteriorate surface water quality. Those interesting equations potentially are useful in formulating water pollution control plan at sub basin scale. For details see Table 2, 3, 4 and 5.

\section{Impact of Spatial Scale on Terrestrial Determinants-Water Quality Relationship}

Results of the current study implied that all scales best explained terrestrial determinants-water quality linkage based on high $\mathrm{R}^{2}$ values [28]. It is well-founded knowledge that terrestrial determinants-water quality linkage varies spatially [6, 29]. [30] found stronger terrestrial determinants-water quality relationship at catchment scale while found the same at buffer scale. [31] exposed that vegetated area in the vicinity of water body play vital role in controlling total solids.

\section{Ecological and Management Implications}

This study illustrates that terrestrial determinants considerably affect stream health at $500 \mathrm{~m}$ buffer and subbasin scale [32]. The developed linear models between terrestrial determinants and water quality parameters can be used in policy making at watershed scale to improve stream health. Models assessment showed that several physico-chemical and trace elements developed fruitful equations with soil texture, village biome and topographic features which can be used at watershed scale to bring improvement in surface water quality using BMPs i.e. vegetation (grassy strips), fine materials and planting trees etc. [33-34]. 


\section{Conclusions}

The current study was carried out to gauge the impacts of terrestrial determinants on stream health at multiple spatial scales at two trans-boundary rivers of Pakistan: The Ravi and Sutlaj. Positive correlation exists between water quality parameters (except DO), and mean population, village land use, coarse grained soil (gravel and sand) and topographic characteristics at all spatial scales. Negative correlation was found between water quality parameters and fine grained materials (silt and clay). Terrestrial determinants especially village land use, coarse grained soil (high permeability) and physiographic characteristic of watershed, mean slope (high erosion) can impair surface waters. On the other hand, fine grained soil can protect stream health due to strong retention capacity and low infiltration capability. All spatial scales best explained terrestrial determinants-water quality relationship based on $\mathrm{R}^{2}$ value. Conservative practices are suggested at riparian as well as catchment scale to account for nearest and furthest pollutants sources. Restoration of riparian ecosystems should be a high priority for water resource conservation in particular along the Ravi and Sutlej rivers and the two plains where there are intensive human activities at village level.

\section{Acknowledgements}

The authors express their appreciation to Pakistan Council of Research in Water Resources (PCRWR), Shuttle Radar Topography Mission (SRTM), Socioeconomic Data and Applications Center (SEDAC) and World Harmonized Soil Database (HWSD) for providing the data for the current research work.

\section{Conflict of Interest}

The authors declare that there is no conflict of interest regarding the publication of this paper.

\section{References}

1. KHAN A.U., JIANG J., WANG P., ZHENG Y. Influence of watershed topographic and socio-economic attributes on the climate sensitivity of global river water quality. Environ. Res. Lett. 12 (10), 104012, 2017.

2. MCCARTHY D.T., JOVANOVIC D., LINTERN A., TEAKLE I., BARNES M., DELETIC A., HIPSEY M.R. Source tracking using microbial community fingerprints: method comparison with hydrodynamic modelling. Water Res. 109, 253, 2017.

3. KEESSTRA S., NUNES J., NOVARA A., FINGER D., AVELAR D., KALANTARI Z., CERDÀ, A. The superior effect of nature based solutions in land management for enhancing ecosystem services. Sci. Total Environ., 610, 997, 2018.
4. KHAN A.U., JIANG J., SHARMA A., WANG P., KHAN J. How Do Terrestrial Determinants Impact the Response of Water Quality to Climate Drivers? An Elasticity Perspective on the Water-Land-Climate Nexus. Sustainability, 9 (11), 2118, 2017.

5. JIANG J., KHAN A.U., SHI B., TANG S., KHAN J. Application of positive matrix factorization to identify potential sources of water quality deterioration of Huaihe River, China. Appl. Water Sci. 9 (3), 63, 2019.

6. SWANSON S., KOZLOWSKI D., HALL R., HEGGEM D., LIN J. Riparian proper functioning condition assessment to improve watershed management for water quality. J. Soil Water Conserv. 72 (2), 168, 2017.

7. KHAN A.U., JIANG J., WANG P. Land use impacts on surface water quality by statistical approaches. Glob. J. Environ. Sci. Manag. 4 (2), 231, 2018.

8. PRATT B., CHANG H. Effects of land cover, topography, and built structure on seasonal water quality at multiple spatial scales. J. Hazard. Mater. 209, 48, 2012.

9. PÄRN J., PINAY G., MANDER Ü. Indicators of nutrients transport from agricultural catchments under temperate climate: A review. Ecol. Indic. 22 (4), 2012.

10. SORANNO P.A., BISSELL E.G., CHERUVELIL K.S., CHRISTEL S.T., COLLINS S.M., FERGUS C.E., FILSTRUP C.T., LAPIERRE J.-F., LOTTIG N.R., OLIVER S.K. Building a multi-scaled geospatial temporal ecology database from disparate data sources: fostering open science and data reuse. GigaScience, 4 (1), s13742, 2015.

11. CAMARA M., JAMIL N.R., ABDULLAH A.F.B. Impact of land uses on water quality in Malaysia: a review. Ecol. Process. 8 (1), 10, 2019.

12. ZENG X., LIU Y., YOU S., ZENG G., TAN X., HU X., HU X., HUANG L., LI F. Spatial distribution, health risk assessment and statistical source identification of the trace elements in surface water from the Xiangjiang River, China. Environ. Sci. Pollut. Res. 22 (12), 9400, 2015.

13. HAMID A., BHAT SU, JEHANGIR A. Local determinants influencing stream water quality. Appl. Water Sci. 10 (1), 24, 2020.

14. LINTERN A., WEBB J., RYU D., LIU S., BENDEMICHL U., WATERS D., LEAHY P., WILSON P, WESTERN A. Key factors influencing differences in stream water quality across space. Wiley Interdiscip. Rev. Water, 5 (1), e1260, 2018.

15. KHATRI N., TYAGI S. Influences of natural and anthropogenic factors on surface and groundwater quality in rural and urban areas. Front. Life Sci. 8 (1), 23, 2015.

16. ISSAKA S., ASHRAF M.A. Impact of soil erosion and degradation on water quality: a review. Geo. Eco. Lan. 1 (1), 1, 2017.

17. KIBRIA K.N., AHIABLAME L., HAY C., DJIRA G. Streamflow trends and responses to climate variability and land cover change in south dakota. J. Hydrol. 3 (1), $2,2016$.

18. DING J., JIANG Y., FU L., LIU Q., PENG Q, KANG M. Impacts of land use on surface water quality in a subtropical River Basin: A case study of the Dongjiang River Basin, Southeastern China. Water, 7 (8), 4427, 2015.

19. BATENI F., FAKHERAN S., SOFFIANIAN A. Assessment of land cover changes \& water quality changes in the Zayandehroud River Basin between 1997-2008. Environ. Monit. Assess. 185 (12), 10511, 2013.

20. BAILLIE B.R., NEARY D.G., GOUS S., ROLANDO C.A. Aquatic fate of aerially applied hexazinone and terbuthylazine in a New Zealand planted forest. J. Sust. Wat. Sci. Manag. 2 (1), 118, 2015. 
21. RODRÍGUEZ-ROMERO A.J., RICO-SÁNCHEZ A.E., MENDOZA-MARTÍNEZ E., GÓMEZ-RUIZ A., SEDEÑO-DÍAZ J.E., LÓPEZ-LÓPEZ E. Impact of changes of land use on water quality, from tropical forest to anthropogenic occupation: A multivariate approach. Water, 10 (11), 1518, 2018.

22. BROOKS A., LIM H.-N., KILDUFF J.E. Adsorption uptake of synthetic organic chemicals by carbon nanotubes and activated carbons. Nanotechnology, 23 (29), 294008, 2012.

23. KHAN A.U., JIANG J., WANG P., ZHENG Y. Influence of watershed topographic and socio-economic attributes on the climate sensitivity of global river water quality. Environ. Res. Lett. 12 (10), 104012, 2017.

24. CHEN Q., MEI K., DAHLGREN R.A., WANG T., GONG J., ZHANG M. Impacts of land use and population density on seasonal surface water quality using a modified geographically weighted regression. Sci. Total Environ. 572, 450, 2016.

25. YE L., CAI Q.-H., LIU R.-Q., CAO M. The influence of topography and land use on water quality of Xiangxi River in Three Gorges Reservoir region. Environ. Geol. 58 (5), 937, 2009.

26. CHEN J., LU J. Effects of land use, topography and socioeconomic factors on river water quality in a mountainous watershed with intensive agricultural production in East China. PloS one, 9 (8), 2014.
27. GLAVAN M., BELE S., CURK M, PINTAR M. Modelling Impacts of a Municipal Spatial Plan of Land-Use Changes on Surface Water Quality - Example from Goriška Brda in Slovenia. Water, 12 (1), 189, 2020.

28. RAMIÃO J.P., CÁSSIO F., PASCOAL C. Riparian land use and stream habitat regulate water quality. Limnologica, 125762, 2020.

29. YE F., KAMEYAMA S. Long-term spatiotemporal changes of 15 water-quality parameters in Japan: An exploratory analysis of countrywide data during 1982-2016. Chemosphere, 242, 125245, 2020.

30. HURLEY T., MAZUMDER A. Spatial scale of land-use impacts on riverine drinking source water quality. Water Resour. Res. 49( 3), 1591, 2013.

31. SLIVA L., WILLIAMS D.D. Buffer zone versus whole catchment approaches to studying land use impact on river water quality. Water Res. 35 (14), 3462, 2001.

32. HUANG W., MAO J., ZHU D., LIN C. Impacts of Land Use and Land Cover on Water Quality at Multiple BufferZone Scales in a Lakeside City. Water, 12 (1), 47, 2020.

33. GIRI S., LATHROP R.G., OBROPTA C.C. Climate change vulnerability assessment and adaptation strategies through best management practices. J. Hydrol. 580, 124311, 2020.

34. MUERDTER C.P., SMITH D.J., DAVIS A.P. Impact of vegetation selection on nitrogen and phosphorus processing in bioretention containers. Water Environ. Res. 92 (2), 236, 2020. 